\title{
A COMPARISON OF BREAST-FEEDING IN TEN CLASSES OF THE POPULATION
}

BY

\author{
MARGARET ROBINSON, M.B., L.M., D.P.H.
}

Assistant Medical Officer of Health for the City of Liverpool.

In a previous paper (Robinson, 1939) it was shown that, though the breastfeeding rate in Liverpool from 1918 to 1937 had not actually declined, it varied from year to year without any apparent reason. In an endeavour to find a possible cause for this I decided to examine the records of all the babies born between January 1, 1930, and May 31, 1940, to group them according to the occupation of the father, and to determine the breast-feeding rate for each group. A difference in the figures thus obtained might account for the fluctuations noted. The cases were limited to those attending the clinic at Norris Green New Housing Estate, Liverpool. A total of 6943 records was collected. Out of these, 5838 were complete. The remaining 1105 were discarded, as 1075 infants ceased attendance while still on the breast, and in thirty cases the occupation of the father was not stated.

It can be seen in table 1 that during the first month the wives of civil servants wean 9 per cent. more babies than do those of labourers and clerks. In the second and third months the weaning rate is highest amongst the semi-skilled and the unemployed classes, whereas it is lowest in the motor-driver class. Between the beginning of the fourth and the end of the seventh month it is low in all classes, and varies by 3 per cent. only. At the eighth month wives of skilled workers and labourers form the greatest number of nursing mothers and those of civil servants the least. The professional group is so small that it may be ignored.

The large numbers contained in the groups of unemployed, skilled workers and labourers made it possible to calculate in each group the yearly weaning rate for ten consecutive years (1930 to 1939). A further thirty-three cases had to be added in order to bring the figure for 1939 up to the total birth rate for this year. The figure for each year includes only the babies born during that year, and the age of weaning is taken from the date of the first supplementary bottle, as in the previous paper. As 1931 contained only ninety-three and 1930 only sixty-four births among unemployed parents, they are both given together under the heading 1931.

Table 2 shows that when these groups are analysed separately a decline in breast-feeding takes place in all, but the variation from year to year still remains. 
TABLE 1

\begin{tabular}{|c|c|c|c|c|c|c|c|c|}
\hline \multirow[b]{2}{*}{ GROLP } & & \multirow[b]{2}{*}{ TOTAL } & \multirow[b]{2}{*}{$\begin{array}{c}\text { NUMBER } \\
\text { UTHLIZED }\end{array}$} & \multirow[b]{2}{*}{$\begin{array}{l}\text { NLMBER } \\
\text { DISCARDED }\end{array}$} & \multicolumn{4}{|c|}{ PERCENTAGE WEANED } \\
\hline & & & & & $\begin{array}{c}\text { 1ST } \\
\text { MONTH }\end{array}$ & $\begin{array}{c}\text { 2ND } \\
\text { AND } \\
\text { 3RD } \\
\text { MONTH }\end{array}$ & $\begin{array}{c}\text { 4TH TO } \\
\text { 7TH } \\
\text { MONTH }\end{array}$ & $\begin{array}{c}\text { 8TH } \\
\text { MONTH } \\
\text { AND } \\
\text { OVER }\end{array}$ \\
\hline $\begin{array}{l}\text { Professional * } \\
\text { Clerks .. } \\
\text { Civil servants } \\
\text { Services . . } \\
\text { Skilled workers } \\
\text { Labourers } \\
\text { Motor drivers } \\
\text { Unemployed } \\
\text { Semi-skilled } \\
\text { Shopkeepers }\end{array}$ & $\begin{array}{l}\cdots \\
\cdots \\
\cdots \\
\cdots \\
\cdots \\
\cdots \\
\cdots \\
\cdots\end{array}$ & $\begin{array}{r}71 \\
760 \\
247 \\
347 \\
1435 \\
1648 \\
478 \\
1456 \\
296 \\
205\end{array}$ & $\begin{array}{r}56 \\
662 \\
202 \\
311 \\
1227 \\
1346 \\
390 \\
1216 \\
255 \\
173\end{array}$ & $\begin{array}{r}15 \\
98 \\
45 \\
36 \\
208 \\
302 \\
88 \\
240 \\
41 \\
32\end{array}$ & $\begin{array}{l}36 \\
31 \\
39 \\
34 \\
34 \\
31 \\
37 \\
36 \\
35 \\
32\end{array}$ & $\begin{array}{l}25 \\
27 \\
26 \\
24 \\
23 \\
26 \\
22 \\
29 \\
29 \\
24\end{array}$ & $\begin{array}{l}14 \\
16 \\
15 \\
15 \\
16 \\
14 \\
14 \\
13 \\
14 \\
13 \\
16\end{array}$ & $\begin{array}{l}25 \\
26 \\
20 \\
26 \\
29 \\
29 \\
28 \\
21 \\
23 \\
28\end{array}$ \\
\hline Total ... & . & 6943 & 5838 & 1105 & & & & \\
\hline
\end{tabular}

* Includes male nurses and school teachers.

The percentage of babies weaned in different class groups by the end of the first, third and seventh months: also the number in each group still on the breast at the end of eight months. The numbers utilized and discarded in each group and the total number of case sheets obtained are included.

TABLE 2

\begin{tabular}{|c|c|c|c|c|c|c|c|c|c|c|c|}
\hline DURATION & GROL'P & 1930 & 1931 & 1932 & 1933 & 1934 & 1935 & 1936 & 1937 & 1938 & 1939 \\
\hline st month & $\begin{array}{l}\text { Unemployed } \\
\text { Labourer } \\
\text { Skilled worker }\end{array}$ & $\begin{array}{l}\overline{20} \\
30\end{array}$ & $\begin{array}{l}41 \\
25 \\
27\end{array}$ & $\begin{array}{l}33 \\
24 \\
26\end{array}$ & $\begin{array}{l}32 \\
27 \\
27\end{array}$ & $\begin{array}{l}36 \\
26 \\
29\end{array}$ & $\begin{array}{l}32 \\
28 \\
43\end{array}$ & $\begin{array}{l}36 \\
41 \\
37\end{array}$ & $\begin{array}{l}33 \\
39 \\
37\end{array}$ & $\begin{array}{l}35 \\
36 \\
40\end{array}$ & $\begin{array}{l}52 \\
47 \\
39\end{array}$ \\
\hline $\begin{array}{l}\text { 2nd and 3rd } \\
\text { months }\end{array}$ & $\begin{array}{l}\text { Unemployed } \\
\text { Labourer . } \\
\text { Skilled worker }\end{array}$ & $\begin{array}{l}-\overline{23} \\
19\end{array}$ & $\begin{array}{l}23 \\
20 \\
20\end{array}$ & $\begin{array}{l}25 \\
24 \\
21\end{array}$ & $\begin{array}{l}27 \\
21 \\
25\end{array}$ & $\begin{array}{l}29 \\
33 \\
22\end{array}$ & $\begin{array}{l}32 \\
26 \\
22\end{array}$ & $\begin{array}{l}34 \\
28 \\
22\end{array}$ & $\begin{array}{l}37 \\
28 \\
27\end{array}$ & $\begin{array}{l}35 \\
32 \\
29\end{array}$ & $\begin{array}{l}26 \\
27 \\
28\end{array}$ \\
\hline $\begin{array}{l}\text { 4th to } 7 \text { th } \\
\text { months }\end{array}$ & $\begin{array}{l}\text { Unemployed } \\
\text { Labourer .. } \\
\text { Skilled worker }\end{array}$ & $\begin{array}{l}-16 \\
16\end{array}$ & $\begin{array}{l}12 \\
13 \\
18\end{array}$ & $\begin{array}{l}10 \\
10 \\
11\end{array}$ & $\begin{array}{l}15 \\
16 \\
16\end{array}$ & $\begin{array}{l}12 \\
11 \\
17\end{array}$ & $\begin{array}{l}18 \\
14 \\
13\end{array}$ & $\begin{array}{l}18 \\
16 \\
20\end{array}$ & $\begin{array}{l}12 \\
14 \\
10\end{array}$ & $\begin{array}{l}15 \\
18 \\
11\end{array}$ & $\begin{array}{r}12 \\
11 \\
9\end{array}$ \\
\hline $\begin{array}{l}8 \text { months and } \\
\text { over }\end{array}$ & $\begin{array}{l}\text { Unemployed } \\
\text { Labourer . } \\
\text { Skilled worker }\end{array}$ & $\begin{array}{l}\overline{41} \\
39\end{array}$ & $\begin{array}{l}24 \\
42 \\
35\end{array}$ & $\begin{array}{l}32 \\
42 \\
42\end{array}$ & $\begin{array}{l}26 \\
36 \\
32\end{array}$ & $\begin{array}{l}23 \\
30 \\
32\end{array}$ & $\begin{array}{l}18 \\
32 \\
22\end{array}$ & $\begin{array}{l}12 \\
15 \\
21\end{array}$ & $\begin{array}{l}26 \\
19 \\
26\end{array}$ & $\begin{array}{l}15 \\
14 \\
20\end{array}$ & $\begin{array}{l}11 \\
15 \\
24\end{array}$ \\
\hline$\underset{\text { utilized }}{\text { Num b e r }}$ & $\begin{array}{l}\text { Unemployed } \\
\text { Labourer .. } \\
\text { Skilled worker }\end{array}$ & $\begin{array}{l}(64) \\
174 \\
138\end{array}$ & $\begin{array}{l}157 \\
138 \\
106\end{array}$ & $\begin{array}{l}113 \\
147 \\
136\end{array}$ & $\begin{array}{l}118 \\
128 \\
104\end{array}$ & $\begin{array}{l}174 \\
141 \\
129\end{array}$ & $\begin{array}{l}148 \\
113 \\
121\end{array}$ & $\begin{array}{l}139 \\
123 \\
121\end{array}$ & $\begin{array}{l}145 \\
134 \\
129\end{array}$ & $\begin{array}{l}127 \\
114 \\
105\end{array}$ & $\begin{array}{l}101 \\
116 \\
107\end{array}$ \\
\hline
\end{tabular}

The percentage of three social classes of babies weaned in each of the ten years under consideration is given for the end of the first month, third month and seventh month. Also the number still being fed at the end of the eighth month. The total number utilized in eacb year and group is given at the foot of the table. 
It is interesting to note that the lowest number in the unemployed group occurs in 1930, and is followed two years later (1932) by the highest breast-feeding rate in all groups at eight months; whereas the highest number in the unemployed group occurs in 1934, and is followed two years later (1936) by the lowest breast-feeding rate in all groups at eight months. A similar result is produced during the fourth to seventh month, but the earlier months are apparently unaffected. If the number receiving help from the Unemployment Assistance Board and Public Assistance Committee may be taken as a rough index of the state of unemployment in the community as a whole, it may be concluded that economic factors do not directly affect the ability to breast-feed but have a remote effect on the duration of suckling only after the baby is three months old. Recently, several mothers have asked me why it is that they fed their first child (now about eighteen months to three years old) when they were poorly fed, owing to their husbands being out of work, and now, when their husbands are earning good money and they are better fed and getting one pint of milk daily, they cannot feed their second infant more than three months without supplementary feeds. It may be that their store of some material essential to breast-feeding was exhausted during the feeding of the first child while on a deficient diet, and that the present diet, increased as it is by animal protein, vegetables and milk, does not provide enough essential food to replace that which has been lost.

Table 2 shows also that the yield of breast-milk in the first month is diminished among the wives of the unemployed, since in this group the highest percentage of infants weaned occurs during this period in each year of the decade under consideration. This inability to lactate may be due to prolonged underfeeding, but, unfortunately, the duration of unemployment is not recorded. It varied from repeated short periods to a continuous stretch of at least ten years. For some unknown reason the weaning rate amongst the wives of skilled workers increased in 1935 to almost the same level as that of the wives of the unemployed, and a year later a similar rise occurred in that of the wives of labourers, and in both cases continued thereafter at this higher rate.

In the light of the above observations it will be interesting to watch the effect of the present fall in unemployment, and of the new milk scheme just started by the Government.

\section{Summary}

The records kept at the Infant Welfare Centre, Norris Green, Liverpool. since the beginning of 1930 were examined and divided into social groups. The weaning rate of each group was calculated and comparisons were made. The three largest classes were each subdivided into groups containing the babies born in every consecutive year for ten years. The weaning rate was calculated and the results were compared.

\section{Conclusions}

(1) There is no real decline in breast-feeding when all classes are considered together over a long period. 
(2) Each class has a weaning rate of its own, but the differences between them is not marked.

(3) During the ten consecutive years (1930 to 1939) there is a real decline in breast-feeding in three social groups. The greatest decline occurs in the first month among the wives of labourers.

(4) Variations in prosperity have not an immediate but a remote effect on breast-feeding, appearing only after two years and limited to the later months.

(5) Continued poverty lowers the ability of the mothers to keep the baby on the breast throughout the first month.

Thanks are due to Dr. W. M. Frazer, Medical Officer of Health for the City of Liverpool, and to Dr. R. E. Bell, Senior Assistant Medical Officer in charge of the Maternity and Child Welfare Department, City of Liverpool, for permission to publish this work.

\section{REFERENCE}

Robinson, M. (1939). Arch. Dis. Childh., 14, 259. 